\title{
The Technological Innovation Controversy
}

\author{
C. Merle Crawford and Gerard J. Tellis
}

76

C. Merle Crawford is a professor of marketing at the University of Michigan at Ann Arbor; Gerard J. Tellis, formerly a sales development manager for Johnson \& Johnson, is a research assistant and Ph.D. candidate at Michigan.

\section{This exhaustive listing and classification of the literature and arguments on technologi- cal innovation contributes toward the dis- cussion of an issue vital to the United States.}

$\mathrm{T}$

The rate of technological innovation is of crucial importance to the material wellbeing of the United States if one or both of the following premises are true-and the weight of general opinion supports them both:

1. Material well-being comes primarily through economic power; economic power flows from technological power, which in turn is directly dependent on technological innovation per se and on innovation in relation to other countries.

2. Material well-being derives from productivity-and productivity is a function of technological innovation.

Experts concur that the rate of technological innovation may no longer be treated as a natural outcome of business activity, but must be constantly analyzed, planned, and promoted-both at the micro and at the macro levels if it is to be maximized.

Many authorities have attempted to analyze recent technological innovation and suggest areas for improvement. However, and this reservation is important, vested interests abound. Most speakers and authors have selected their data carefully, with the intention of promoting a particular position. The result has been a flood of speeches, articles, and reports, statements of position and counterposition, of attack and counterattack. Readers and listeners have been inundated with data, conclusions, imperatives, accusations, and lamentations, each of which seems responsible and reliable, yet which is inevitably only a piece of the total picture and, taken together, are actually quite contradictory.

Because of the importance of the topic and the extent of the debate, we attempted to review all of the recent literature to arrive at an unbiased evaluation of the entire situation. In particular, answers were sought for the following questions:

1. What has been the recent rate of technological innovation?

2. If there has been a decline, what is it attributed to?

3. Are there contrary observations? That is, do all of the data support the same conclusions?

We look at the rate of technological innovation in this country and compare it to that in other countries.

\section{Current Rate of Innovation?}

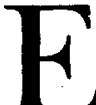
ven though it is generally argued that the rate of U.S. technological innovation is declining, there is no one simple statistic quantifying this rate, so 
observers have used various surrogate indicators; the most common statistic used is the rate of change of R\&D expenditures. Business Week summarized the situation this way:

"The slowdown in research spending has been dramatic. From 1953 to $1961, \mathrm{R} \& \mathrm{D}$ expenditures adjusted for inflation increased at an average rate of 13.9 percent a year for government, and 7.7 percent a year for private organizations. From 1961 to 1967, government-funded R\&D increased 5.6 percent a year and private R\&D increased 7.4 percent a year. But, from 1967 to 1975 , governmental R\&D shrunk 3 percent a year and non-government spending rose a mere 1.8 percent a year."

The constant dollar amount increased from $\$ 29$ billion in 1967 to $\$ 31$ billion in 1975 . Consult Robert $\mathrm{C}_{\text {. }}$ Dean for additional data and different modes of expression on the subject of total spending. ${ }^{2}$ See also the latest addition of the Statistical Abstract which summarizes the available NSF data.

More critical, however, is the portion spent on what is commonly identified as the " $R$ " portion of R\&D. Definitional problems abound, but the sources most commonly cited show that again the answer depends on the time period selected. Frank H. Healey offers the most thorough analysis for the years just prior to 1977 , the declining period. ${ }^{3}$ Total constant dollar expenditures on basic research fell from a 1968 peak of almost $\$ 4$ billion to a 1976 level of $\$ 3.5$ billion. Industry's portion of this total, always very small, was up only slightly, while the federal portion fell sharply.

From 1960 to 1976 industry's percentage of $R \& D$ spent on basic research fell from 7.3 percent to 4.3 percent. All four of the major spending industries (chemical, electrical, machinery, and aircraft) suffered sharply reduced expenditures on basic research from 1968 to 1976, and spending for basic research in all three of the primary disciplines (chemistry, physics, and engineering) also fell sharply; the total decline was kept from being even worse by slight increases in the biological sciences. Industry's contribution to basic research in universities, Healey felt, "is so minute as to be considered negligible (less than 3 percent) for the past ten years" (p. 14).

Other researchers have also expressed concern over the reduced level of basic research activity. Michell C. Lynch found that, based on 1972 dollars, universities' basic research outlays slipped to about $\$ 399$ million in 1977 from $\$ 417$ million in $1971 . .^{4}$ Business Week reported that the National Science Foundation estimates that real industry basic research dollars were off 12 percent from 1965 to $1975 .^{5}$ The comparable federal figure was off 45 percent. George Manners and Howard Nason reported that in 1958 industry spent 38 percent of its $R \& D$ budget on basic and applied research, but only 25 percent in 1976 , in 1977 , and in $1978 .^{6}$

Another popular statistic used is R\&D expenditures as a percentage of GNP, and on this Edward David says the proportion "declined from over 3 percent in the mid-sixties to 2.2 percent today." 7 Considering the magnitude of GNP, this is a dramatic decline. The decline, incidently, is due to federal cuts, since the civilian expenditure as a percentage of GNP did not decline during that time; moreover, the percentage later rose to 2.5 percent in 1977. Some object to using either total R\&D or the total basic research portion as indicators of innovation, since increases in total spending are probably due to increased dollars spent on energy and environmentally related problems, on developing new manufacturing processes, and on improving present products. H. R. Clauser cites a McGraw-Hill survey which estimated that only 28 percent of total R\&D budgets in 1977 would be spent on new products. ${ }^{8}$

Another surrogate statistic is the number of technological breakthroughs. It is generally claimed there have been fewer major breakthroughs recently. Though comparisons are frequently made to the fabulously productive $1950 \mathrm{~s}$, this claim is difficult to document, and few have tried. John Hanley did note that "in the fifteen years preceding 1962 there were 641 new drugs introduced in this country. But the next fifteen years have produced only 247 new drugs." 9 Even this one supporting statistic is now partially refuted by data which disclose that the FDA approved twenty-three new compounds in 1978 , the most since $1967 .{ }^{10}$ The case of pharmaceutical specialities 
is discussed at length in the Environmental Health and Safety Regulation draft report. ${ }^{11}$

Capital investment is increasing more slowly in recent years, suggesting that inventions must be of less economic significance (David). The Economic and Trade Policy draft report shows that the rate during the seventies is only onefourth that of the previous twenty. five years. ${ }^{12}$ William E. Simon cites a Treasury Department report to this effect also, ${ }^{13}$ and the Small Business draft report shows that the capital investment fall-off is even greater for small businesses. ${ }^{14}$

Productivity in R\&D is off. Dean makes an extensive analysis of capital investment, growth in GNP, numbers of scientific personnel, and other factors to support this claim.

Fewer new technologically based companies are being formed. Though documentation of this claim is difficult, Chemical and Engineering News says that 204 new publicly financed small technical companies came into being in 1969 , but that by 1975 "this number had dwindled to virtually zero."15 The Small Business Draft report called it a "dribble." Business Week ("The Breakdown") supports a statement by Richard S. Morse of MIT to the effect that new high-technology growth companies are no longer being formed "in sufficient numbers to provide the jobs and technical products for export which will be needed in the years ahead." The Small Business draft report (pages 2-3) cites MIT studies showing the very great im- pact of newer high-technology firms on the number of jobs.

Fewer technically trained people have been made available in recent years. The report by Geoffrey Place shows that since 1960 there has been a steady decline in the percentage of first degrees granted by colleges that went to physical/life sciences and engineering. ${ }^{16}$ Even the absolute numbers have decreased in recent years, with 37,970 engineering degrees in 1976 compared to 44,190 in 1972 .

Finally, there has been a barrage of rather minor or incidental claims, mostly undocumented. For example, it is said we have fewer technical publications today, a declining share of the world's scientific articles, and fewer Nobel prizes awarded in the technological fields.

\section{In Comparison to Other Countries}

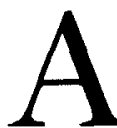
critical part of the argument developed for increased technological innovation concerns the position of the United States relative to other countries, especially to Japan and Germany, and occasionally to Russia, the Common Market, or foreign countries in general.

Growth in total U.S. R\&D expenditures has been less than that of other countries. According to Dean, "in the 1974-79 period, the U.S. R\&D budget was growing by about 3 percent annually which is less than the growth of the economy. Germany had an 8 percent growth, Italy 11 percent, and Japan 13.5 percent."

Lynch found " $R \& D$ spending in the U.S. beginning to slacken in comparison with the rest of the world. One government study estimates that the U.S. currently does only about 20 percent of the world's R\&D, down sharply from 50 percent about ten years ago." Several of the Policy Review draft reports speak to this point.

U.S. R\&D as a percentage of GNP is slipping relative to other countries. According to Lynch, U.S. expenditures for R\&D (2 percent of GNP) currently trail the 2.3 percent level in Germany and the estimated level of more than 3 percent in the Soviet Union.

Dean took these figures and combined them with data on capital expenditures to determine what he calls the "bite for the buck." He calculated several nations, GNP relative to reinvestment in $R \& D$ and in plant for the period 1955-65, and obtained a figure of 0.7 for the U.S. and less than 0.6 for Europe, Japan, and USSR. However, for 1965-70, our figure was 0.2 , compared to 0.8 for Europe, 0.7 for Japan, and 0.5 for USSR. Even though we reduced expenditures on R\&D and capital investment during that latter period, our productivity was reduced as a result of the even lower expenditures.

Other countries are devoting more manpower to technology. Dean calculated the total number of scientists and engineers divided by GNP, and found that the U.S. figure was slightly greater than those for West Germany and Italy, but less than half that for Japan. Furthermore, in the early 1970 s West Germany, Italy, and Japan 


\section{"Even though it is generally argued that the rate of U.S. technological innovation is declining, there is no one simple statistic quantifying this rate."}

were increasing their professional R\&D manpower, whereas we were decreasing ours.

We are losing the patent war. Both Arthur Gerstenfeld and Lynch speak to this point, but perhaps Robert Irving says it most succinctly: "The number of U.S. patents granted to U.S. residents declined by 21 percent between 1971 and 1976, while U.S. patents issued to foreign residents grew by 16 percent in the same period, so that they are now 37 percent of the total."17 Since Irving's report, the foreign percentage has increased to 40 percent. ${ }^{18}$ U.S. inventors ar also getting a sharply reduced share of patents granted by foreign governments. The entire patents situation was reviewed in depth in the Patent Policy draft report issued by the Department of Commerce. ${ }^{19}$

The United States's share of major innovations is declining. Alok K. Chakrabarti, et al. studied the 500 most important innovations developed in the world from 1953 to 1973 . They found that the U.S. share of worldwide output fell from 75 percent in $1953-59$, to 62 percent in 1960-66, and to 56 percent in 1967-73. This decline was not due to lessened productivity on our part-we held at 106, 108, and 105 innovations, respectively-but rather to an increased output in other countries, especially the United Kingdom, West Germany, Japan, and France. ${ }^{20}$

We are rapidly exporting our technological capabilities. The Conference Board reported that in 1964, \$264 million were remitted to U.S. corporations from firms abroad, as fees and royalties for processes, formulas, techniques, etc. ${ }^{21}$ By 1973 such payments had reached $\$ 1.5$ billion and were still growing. "This six-fold increase over the decade indicated a rapidly expanding international flow of technology." Joseph M. Leightman combines this point with the previous one on patents to remind us that 66 percent of the $\$ 143.6$ billion of total U.S. exports in 1978 consisted of manufactured goods embodying patented subject matter. $^{2} 2$

\section{Causes of the Decline}

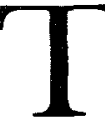

The above discussion of actual rates of technological innovation shows the many opportunities for the intrusion of the natural bias of vested interests; but the problems there were nothing compared to what follows when we try to ascertain the reasons for the deteriorating situation. Every possible cause for those declines seems to have been cited by someone, somewhere. However, the general thrust of attack has centered on three categories of cause: (1) governmental actions, or lack of them; (2) practices within business; and (3) forces stemming from social change within society at large. We will look at each category in turn.

\section{Governmental Causes}

The Regulatory Process. The regulatory situation is complex, and can itself be broken down into six specific sharges. (A new classification of seven specific charges appeared in the Regulation of Indus- try Structure draft report, ${ }^{23}$ but the charges here echo the general business press more accurately. The draft report, however, is an excellent source of data and examples.) Regulation in general is a growth industry and is massively oppressive. Product innovation is especially affected by NHTSA, OSHA, EPA, FDA, EEOC, FPC, ICC, and the Justice Department, although hundreds of other bureaus and departments have been cited. Evan F. Binkerd perhaps summed it up best in a 1978 speech to a food and drug law institute in San Diego:

"U.S. News and World Report says that $\$ 4.9$ billion is earmarked for regulation of business during fiscal 1979, an increase of 6 percent over Ford's last budget and double the total five years ago. Business spends about $\$ 20$ on compliance costs for every tax dollar government spends on regulation-according to 1976 estimates made by the Center for the Study of American Business-putting total costs at $\$ 200$ billion." 24

Even if these costs could be passed on to domestic buyers, the American firm is weakened in competition with less-regulated foreign competitors in world markets.

Richard Foster and Frederick Gluck found that the FPC planned a 60 percent increase in cases brought to court in 1976 over 1974, the ICC instituted 36 percent more cases, and the $\mathrm{CAB}$ instituted 138 percent more investigations and actions. ${ }^{25}$ Justice Department "actions have been aimed at breaking up oligopolies in the electrical equipment, machinery, motor vehi- 
cle, chemical and petroleum industries. These technology-intensive industries contribute about 80 percent of the total U.S. companysupported R\&D in the United States." Ironically, some critics of regulation claim that it actually leads to the very industry concentration which the regulators abhor, since small firms are less able to afford the costs. Chrysler management made this point often during its plea for federal support in late 1979.

Regulatory activities force a diversion of $R \Theta D$ funds from innovation in new products. Manners and Nason said:

"The IRI has found the following compound annual growth rates in spending (in current, not deflated, dollars) for $\mathrm{R} \& \mathrm{D}$ devoted to:

Proposed legislation

$19.3 \%$

OSHA

$16.0 \%$

Environmental considerations $15.4 \%$

Product safety

$10.0 \%$

Other governmental

regulation

When overall R\&D budgets are not growing this fast, other categories of research ... must be suffering." In 1972, according to Lynch, the pharmaceuticals division of Norwich-Eaton Products, Inc., submitted 456 volumes of technical material, each volume two inches thick, when seeking regulatory approval from the FDA for a new muscle relaxant. Even if "zero-risk" can be defended in the case of pharmaceuticals, Gordon M. Graff cites other instances where it is a needlessly or even hopelessly expensive policy. ${ }^{26}$.
Regulatory activities force jobs overseas. Lynch again cites the drug industry: "In fact, approval in the U.S. generally lags so far behind other countries that American pharmaceutical companies have established manufacturing abroad, in part so as not to lose out in foreign sales." Warner Lambert says U.S. merger law will not allow the types of acquisitions they want to make, so they have been acquiring foreign firms and marketing products back into the U.S. from these units.

Antitrust action inhibits innovation. This charge takes several forms, which are described and documented in the Regulation draft report (pages 26-29). The major concern is that federal actions attack the very firms which have shown the greatest technical innovation capability. IBM and AT\&T are examples, and Foster and Gluck recently asked: "Would Bell Labs have the record it has if AT\&T had been forced to divest it years ago?"

Furthermore, the Justice Department is against research and development consortia-joint company activities which have apparently been so successful in other countries. Not only does the Justice Department disapprove such consortia when proposed, but the U.S. government, unlike the governments of other countries, does nothing to encourage them (Foster and Gluck).

Innovation's boosters feel that government antitrust policy declares bigness bad, high shares of market bad, and high profits bad. Ironically, a successful innovation program is designed to achieve ex- actly those goals which supposedly signal monopoly.

Regulators make it difficult to acquire, and hold, new patents. DuPont's chairman, Irving S. Shapiro, recently said that "getting patent approval on new discoveries frequently has involved protracted court fights before judges and juries incapable of understanding the technical complexities involved, and, more often than not, unfavorable judgments were returned against the patent holder." 27 The Patent Policy draft report details some of the patent invalidity statistics and costs (p. 3), which are all negative; however, the report also quotes appellate judge Howard $T$. Markey in a 1971 study which showed that, of the more than one million patents then still "alive," only 1,081 had been litigated $(0.1$ percent), and only around 11 percent of those were taken to appellate courts. Markey feels the patent invalidity charge is without merit (p. 8). Finally, companies such as General Electric would seem to call into question the difficulty of getting patents-according to Robert R. Jones, G.E. acquired 865 new ones in $1978 .^{28}$

Most serious of all, the entire regulatory process in this country creates uncertainty-the greatest single enemy of technological innovation. In an excellent summary of the role of government in the innovative process, Kenneth E. Knight and Helen R. Baca say: "The instability and seeming irrationality create an extremely uncertain environment for business. Administrations change; turnover within govern- 


\section{"The general thrust of attack has centered on categories of cause [of technological deline]: governmental actions, or lack of them; practices within business; forces stemming from social change within society at large."}

ment agencies is large; laws passed (e.g., EPA and OSHA) are continually being reinterpreted .... Often, a business outcry against any government regulation is a plea for consistency ...."29

Eaton's story on its trials with the automobile airbag, as just one example, is vividly described in Fortune. ${ }^{30}$ Perhaps worst of all, various agencies and/or branches of government frequently catch industry in the cross fire of a jurisdictional dispute.

Before leaving the subject of regulation, however, it should be noted that regulators reject these arguments. We often hear the claim made by Wil Lepkowski that there is no evidence that regulation has actually retarded innovation. ${ }^{31}$ Graff (p. 38) quotes Jordan J. Baruch as questioning the "innovation gap," Pennwalt's Gerhard Barth-Wehrnalp as referring to "the alleged lag," and Edward D. Jefferson's claim that DuPont had a constant rate of new product introductions during the period 1958-1977. The pharmaceutical industry's opposite experience is cited elsewhere.

Government's motivators are frequently misused, reducing funding for selected programs. Cuts made in defense and space development programs need no documentation, but not so well known are cuts made in National Science Foundation spending-especially the abandonment of the RANN program.

Program funding goes to safer technologies. Governmental procurement personnel are risk-averse, so contracts are often awarded to firms proposing to utilize only proven technologies rather than to firms willing to attempt innovation. Mass transportation and municipal water treatment are two areas occasionally cited. Similar problems are cited in the Procurement draft report. ${ }^{32}$ But an article in Chemical and Engineering News probably makes the major point when noting that government procurement offices could actually outproduce regulators if they used innovative "carrot" techniques. ${ }^{3}$ "It's a matter of "demand-pull" vs. "supply-push."

Tax laws don't stimulate. It is frequently charged that our tax laws penalize technological success, offer no direct rewards for achieving socially worthwhile technical breakthroughs, and in fact encourage debt rather than savings (Graff). Capital gains taxes are higher in the United States than in many other countries, as are dividends taxes. The tax question is complex, however, and highly debated, as shown by the discussion in the Regulation draft report (pp. 6-14).

The lack of a general overall governmental push for innovation. T. Dixon Long of Case Western Reserve University recently contrasted Japan and the USSR. "The Japanese research and development budget is unified and the thrust of Japanese innovation is coordinated and even directed by the government. It is a fundamentally different approach for bringing new technology from laboratory to profitable application." 34 Conversely, the Soviet system provides incentives on production targets, encour- aging managers to set the targets as low as possible and thereby discouraging (becoming a barrier to the process of) innovation. This accounts for the rapid progress in Japan and the slowdown in the Soviet Union (from which Japan benefits accordingly). Bela Gold's analysis of the Japanese steel industry is an excellent case in point, ${ }^{35}$ as is Robert Wesson's brief article on the current Soviet situation. ${ }^{36}$ Both authors indicate that the U.S. "problem" will increasingly be shared with those countries.

\section{Miscellaneous Government Factors}

The political process is a negative force. James Quinn makes the point by describing the dilemma of automobile executives: if they manage to do the technologically impossible, they are called liars for saying they couldn't do it, but if they fail, they are called footdraggers for not really trying. ${ }^{3}$

U.S. programs of direct aid to other countries. The U.S. government actually activates programs designed to aid foreign competitors, an example of which was announced in 1978 by President Carter: the Foundation for International Technological Cooperation (FITC). ${ }^{38}$ Although perhaps a worthy contribution to the development of depressed nations, the FITC nevertheless is instructed to encourage the exporting of U.S. technical know-how.

Monetary and fiscal policies discourage technological innovation. Quinn points out how alterations in the money supply have increased interest rates and thus discouraged 
long-term investments in technology. Federal actions have been cited as holding down stock prices and reducing the pool of equity capital so essential to innovation in the smaller firm.

\section{Practices Within Industry}

In addition to the governmental forces discussed above and the socially oriented ones that follow, some observers find within industry itself strong forces which reduce technical innovativeness.

A General Policy of Caution. William P. Sommers cites a common criticism of business managements today: "Ignoring all specifics, many firms have leaders who have decided that caution is the best policy. Whether due to governmental actions, stock markets, or whatever, there is a feeling that too many managements simply avoid anything that smacks of risk." 39 This charge is more often a hopeless lament than a call to action-for example, see the comments of long-time inventor Jacob Rabinow in "U.S. Promotes Patent File."

Forces Relating to Dollars. There is a shortage of funds for innovation. Although extremely difficult to document on a macro basis, it is generally felt that American firms face an acute shortage of funds for application to technological innovation. Larger firms find stock market prices inhibit their securing more equity capital; smaller firms not only face a critical and suspicious market, but also the vagaries of venture capital sources. This issue is debated, however, and some observers, including C. J.
Mosbacher, even claim that there has recently been an increase in venture capital. ${ }^{40}$ But data in the Patent Policy draft report adequately document a worsening problem in the U.S. relative to competitive countries, as well as the disappearance of small-firm stock offerings (page 1).

Inflation is also cited as a cause of a decline in funding. It is argued that funds earned from the past are increasingly worth less and thus constitute a smaller pool for reinvesting. ${ }^{4} 1$

Non-R\&D costs take increasing portions of available funds, and bringing a new technology from the lab into the market seems to get steadily more expensive (the average pharmaceutical product now takes more than twelve years). Some firms have noted that new product costs for non-R\&D activities now exceed $R \& D$ costs by a considerable margin, and the Domestic Policy Review subcommittee for economics claims that "90 percent of the investment necessary to bring an innovation successfully to market comes after the innovation process is complete" (page 6).

After marketing the innovation, factoring out inflation, and setting aside dollars to replace equipment, returns are often discouraging. DuPont's Shapiro said, "On any realistic index, corporate profitability has been going down in the United States for most of the past twelve years. There isn't much left to support new ventures" ("Chairman Laments Decline," p. 28). Michael Blumenthal, while Secretary of the Treasury, said after-tax corporate
ROI fell from 8 percent to 4 percent during the decade preceding 1976 (Economic and Trade Policy draft report, 1978, page 2).

Forces Imbedded in Technology Itself. Increased technological innovation will require both technical and economical attractiveness, which some observers feel technology lacks.

First, they claim that the opportunity for technology may be disappearing-that there is a steady lessening of the "pool of the undiscovered." Decreasing marginal advancements in automobiles, air transportation, consumer communication, and housing are offered as evidence, but such pessimism is laughed off by others: for example, see the discussion of genetic engineering in Business Week. ${ }^{42}$ Gordon C. McKeague comments about biotechnology in the same article. In the latter case Standard Oil of Indiana is successfully leaching lean ores with bacteria. Dun's Review offers the best recent summary of exciting developments currently underway along the frontier of technical innovation. ${ }^{4} 3$

Additionally, some observers point to disappointments from investments in basic research-many are convinced that basic research just doesn't pay. Richard E. Heckert, senior vice president for research at DuPont, recently said, "Why risk money on new businesses when good, profitable, lowrisk opportunities are on every side?" DuPont recently announced that they cut their new business ventures from twenty-four to six during 1975.44 


\section{"Most serious of all, the entire regulatory process in this country creates uncertainty - the greatest single enemy of technological innovation."}

Companies today are also interested in putting money into process technologies rather than product technologies. Such investments cut costs and lead to lower prices and, hopefully, to increased market shares.

However achieved, there is strong motivation to spend first to protect a market position. Dr. George Mechlin, head of Westinghouse Research Laboratories, recently said, "We're concentrating on the products and technologies in which we have a well-established position.", 5

Lastly, technology works against itself by leaving a large backlog of unexploited discoveries from earlier breakthroughs.

\section{Competition as a Negative Force}

$\mathrm{R}$ ecent years have seen market segmentation and product positioning become the law of the marketing plan. Technological development has followed this trend, with the result that product life cycles are increasingly being shortened by competitive product innovation and that the potential return from any one technological advance is restricted to smaller and smaller segments of what were once large markets.

Foreign competition is also a factor, as we now pay the price of many years of technological exportation. Richard K. Pitler, vice president and technical director for $\mathrm{Al}$ legheny Ludlum Steel Co., recently pointed out that two to four years is the most the innovative nation can expect as an exclusive on new steel production technology. ${ }^{46}$ This fact leads some to conclude that foreign competition inevitably ends up destroying the motivation for further technological development in the innovating country. However, some observers feel quite differently on this point. The Economic and Trade Policy draft report actually encourages foreign competition here as a spur to still further innovation (p. 25), and some preliminary research by Turvia Blumenthal suggests that the whole question of technology exporting is too complex for simplistic generalizations either way. ${ }^{4}$

Shortage of appropriately trained personnel. Given desire, opportunity, and money, a management still cannot be productive in technological innovation without appropriate manpower. One shortage today is managerial-particularly that rare manager who, as David put it, "can span all the steps of innovation, let alone manage them effectively.",

Most of the voiced concern, however, focuses on the engineer or scientist. Geoffrey Place put it this way: "Figures available from the Engineering Manpower Commission show that the absolute number of graduating engineers has actually gone down each year since 1972 "-from 44,190 in 1972 to 37,970 in 1976 . Within the technical field, he also notes that "the ratio of graduating engineers to graduating scientists has been declining .... we have moved from a position in 1960 when seventythree engineers graduated for one hundred scientists, to the position in 1972 when forty-five engineers graduated per one hundred scientists." Place strongly feels that engineers contribute more directly to the technological innovation task in industry than do scientists.

For the future, Clauser says "the annual number of bachelor degrees in engineering will average about 10 percent below the 54,000 needed to meet projected demand for the 1972-85 period ... chemistry 11 percent below."4 8 Later estimates by Anne C. Roark, however, indicate that the future supply is now felt to be more than adequate. $^{49}$ Lastly, even if the supply of engineers and other technically trained people is adequate, they may be improperly trained. Glenn Gilman quotes Donald Schon in 1966: "Today, many schools treat engineering as an applied science. Instead of teaching a man how to run a generator or design a beam, they teach him physics and mathematics." 50 Charles Stark Draper of MIT said, "Schools have generally abandoned the teaching of engineering or reduced emphasis so greatly that graduates have little understanding for design, systems ... and usually must be reeducated by employers before they can become effective members on the teams of technology." Gilman concludes: "We have little basis for assuming that our colleges and universities are graduating engineers ... who are likely to become innovative entrepreneurs ..."

The problem lies with management. The most popular criticism of management involves what some call the "MBA Syndrome." W. 
Halder Fisher, of Battelle Memorial Institute, sees a current top management which is transient, has little entrepreneurial stake in the business, is motivated by executive incentive programs which emphasize "accounting" concepts of achievement, seeks corporate growth through acquisition, and is responsive to managerial control which is oriented to short-term results. ${ }^{51}$ Buried in that reference to "accounting" concepts of achievement lies the real culprit, according to many-and it concerns the financial analysis of proposed and progressing projects. Asking technological innovation to prove the probability of a reasonable return on invested funds acts to thwart all but low-risk programs. Chester Carlson could not have made such an analysis on xerography. Henry Ford would perhaps not have developed the assembly line had he needed a discounted cash flow showing an internal rate of return of at least 40 percent. It is said that real innovation comes from the heart, not the income statement. Many observers discuss this subject, among them Quinn, David, and Frank Press. ${ }^{5}$

The newest tool of product development management, the product innovation charter, or strategy, is also suspect. Many managements have decided what characteristics of innovations they feel can most optimally be exploited by the firm, and are asking their research and development operators for them. Research people decry such "fences" on their creativity.

Besides the above deliberate managerial modes that restrict inno- vative activity, critics point to the unintended results of bureaucracy in many modern managements. Most technological innovation today is being carried out in large firms, evidenced by the fact that in 1976 the top ten R\&D performing firms accounted for over 36 percent of all expenditures, and the top 10 percent of such firms accounted for 70 percent of all expenditures (Manners and Nason, p. 9). Gilman (pages 16-17) simply says that the characteristic process of invention and innovation is inconsistent with the nature of complex organization, and quotes Richard Stillerman: "The record of modern invention demonstrates that it is the quality of the researcher, not the elaborateness of his equipment, that determines success." He also quotes Princeton's Frederick Scherer: 'Big firms have certain environmental characteristics which seem, on $a$ priori grounds, likely to discourage technological progressiveness." Gilman goes further to criticize the use of market research, saying that market research would have studied prehistoric transportation and recommended further innovation in travois and sled technology, and certainly would not have recommended the wheel. Interestingly, however, business has used the advantages of size to defend acquisition of small high-technology companies against antitrust charges.

Exactly how the management systems of the large firm act to inhibit innovation is not entirely clear. Certainly the "Not-InventedHere Syndrome" is commonly mentioned. Ray-O-Vac struck at the problem of organizational levels re- cently when they abolished one level of executive vice presidents, ${ }^{53}$ yet $3-\mathrm{M}$ is a large firm which seems to have organized around size to achieve small-firm dedication to innovation.

The tactic of divisionalization is itself also cited as a cause of managerial mishandling of innovation. Divisionalization tends to produce a short-term focus on the part of division management; as Arthur Gerstenfeld said: "It is clear that U.S. managers change jobs over relatively short periods of time and that the rewards associated with risks are not realized... punishment for failure is often unemployment and loss of promotion possibilities," while this is not true in Japan. ${ }^{5}$

The charge is sometimes carried right to corporate top management, and its lack of overall commitment to the high risk of dramatic innovation. A few examples from a 1976 Business Week study make the point:

General Signal Corporation: "A new product is simply one with a low saturation, high consumer appeal and a strong profit potential."

Gould: "The main thing a fellow in my position can do is turn things off."

Owens-Illinois: "We're not expanding, but we're running the business we know better."

A consultant in technology: We have "run into endless corporate roadblocks and indecision-one company changed product managers five times during one development."

Thermo Electron Corp. (a supplier of technology to larger firms): 


\section{"Product life cycles are increasingly being shortened by competitive product innovation and ... the potential return from any one technological advance is restricted to smaller and smaller segments of what were once large markets."}

"We constantly run into the attitude of 'let someone else go first'-even for processes proved overseas." 5

Perhaps important in this regard is the matter of top executive tenure, since there seems to be a reduction in the number of years an office is occupied by a specific president or general manager. Dean cites a Battelle Memorial Institute study of the innovation process and reports "the average time to complete the innovative process is 19.2 years ... one half of a man's career. But management's time horizon is only about 3 years."

Given that keeping a good price on company stock is known to be rather essential to top executive tenure, a basic bias against longterm, speculative technological innovation is perhaps to be expected. So is the strong current tendency toward acquisition as a mode of gaining a technological advantageit is more certain, quicker, and less risky, albeit offering less long-term gain (see Graff, p. 38).

The problem lies with labor. Another argument holds that top management's general aversion to high-risk innovation is more a function of their anticipation of the workers' reactions than of their own desires. Gerstenfeld says unions in the United States and Europe are often anti-innovative when innovations affect the labor market, but that Japanese labor is not. In general, one could hardly expect enthusiastic labor reaction to any product development which threatened the continuation of jobs based on previous product technol- ogy. The Labor Advisory Subcommittee draft report supports these concerns when citing collective bargaining as key to meeting the "dangers of innovation and new technology."5 6 Further, according to Business Week, labor is talking of a greater role in $\mathrm{R} \& \mathrm{D}$ project selection so as to help assure more, not fewer, jobs. 5

\section{The Problem Is With Society}

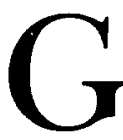
iven that the above analysis indicts governments, industry, and labor, there are those who feel the real culprit may be outside the control of any of the groups-lying instead deep within the psychological and social makeup of our nation's population. There are several reasons cited for this feeling.

Society has lost its taste for excellence. Combining a wide array of forces from the late sixties, a case can be made for the feeling that the American people reject elitism and opt for egalitarianism. They no longer want to lead the world or to be the best in everything. As David put it, "The Nation seems to be losing its taste for excellence and dedication. We are opting for bland, stodgy, marginal competence. Technological innovation is perhaps the first to suffer under this deterioration" (p. 8).

A declining number of still unmet major needs. Some feel technology is its own worst enemy, because as we succeed in solving the major problems of mankind there is increasingly less for technology to do. Perhaps the pharmaceutical in- dustry makes this point. In 1950 the nation's health needs were broad and critical-so hundreds of new drugs resulted. Now, the cate gory of diseases still requiring major research is rapidly being narrowed to long-term degenerative problems of complex character, which are not particularly amenable to the dramatic short-term solutions typified by the Salk vaccine. It is claimed, for example, that no drug firm would have difficulty gaining money, good management, personnel, or government support for a polio program today, were there still a polio problem. Beyond drugs, we have housing, clothing, food, and the like-all of them areas of major concern at some time in the past, but less so now. Needless to say, persons concerned about energy, urban living, the problems of aging, and so on, quickly disagree.

People are selectively negative toward technology. Newspapers and television have made quite clear the concerns of many Americans about the SST, nuclear power, computerized data banks, chemical damage to our environment, genetic engineering (intervention research), and many other subjects. Technological innovation is felt to have negative side effects or by-products, and some observers credit negative social attitudes toward these as a key force inhibiting further work. The Public Interest draft report said: "... innovation to what end? ... Does the innovation being promoted improve the quality of life?... Who are the beneficiaries?" 8 Helen Nelson also spoke the critics' concern over "frivolous 
innovation-the synthetic potato chip, the longer cigarette, or the electric hot dog cooker" (Graff, p. 38).

Fortunately for innovation, the general public is not antitechnology per se, as evidenced by acceptance of contact lenses, instant cameras, CAT-scanners, hand calculators, lasers, and scores of other recent advances.

Greater social interest in nontechnical problems. Increasing attention is given by many of society's spokespersons to those problems which are less amenable to technical solution-urban crime, unemployment of selected segments of the population, safety, education, and race relations, as examples. To the extent attention and funds go to these problems, there is less for technical innovation. It is easier for these "grave social concerns" than for new fiber optic processes or biochemistry to become hot political issues.

\section{Contrary Observations}

$\mathrm{W}$ e have inserted, at various points in the above presentation, contrary observations or data, but the essential thrust of our presentation is to show the viewpoint of various persons who are calling for a wide array of actions to alleviate the recent shortfall in technological innovation. Before concluding the discussion, however, it should be made evident that there is significant opposition to virtually every point made, to the conclusions, and to the recommendations for reme- dial action. This opposition comes from all quarters, including the business community itself.

\section{The State of Technology}

Robert Irving cites the availability of large bundles of unexploited technical breakthroughs already achieved (p. 69), and further suggests that the dollar decline in R\&D expenditures must be regarded in the knowledge that earlier years included war research, and that the U.S. was one of the few intact developed economies in the fifties. During much of the $1950 \mathrm{~s}$ and 1960s, we were exploiting foreign breakthroughs, and there is little evidence to suggest that any critical area of human need-except possibly energy-has suffered a dollar decline, even if the total did go down. Charges and countercharges confuse dollar outlays (input), utilization (management), and output (e.g., patents). A shortfall in one does not necessarily mandate a shortfall in another.

\section{Government's Role}

Beyond the obvious issues of industry's inherent tendency to blame government for its problems, the difficulties government people face when they actually attempt deregulation (e.g., airlines), and the fact that governments are political institutions responsive to the perceived will of the electorate, there are more basic issues.

First, government support may be actually increasing. According to Richard J. Levine, "Total outlays for basic research are projected at $\$ 4.3$ billlon in the coming (1980) fiscal year, up 12 percent from the present level." 59 The NSF Budget is up 11 percent. The 1979 figures also reversed earlier trends.

Second, government is aware of the problem and has taken many actions, especially the establishment of the 1,000-person Domestic Policy Review on Industrial Innovation. To date, White House reactions to the committee reports have been disappointing to industry, but the many draft reports are being read widely.

Third, the action needed from government may be more in the policy area than in dollars or regulation. Robert Levy feels that we have the technical capability now to make massive strides on energy, for example, but that we lack a realistic energy policy..$^{6}$

Lastly, the call for more government assistance is often terribly general and unsophisticated. According to Clauser ("The Role of Industrial R\&D"), Jordan Baruch has made the point that government assistance must vary according to such factors as company size, industry life cycle stage, capital-vs. people-intensity, technology status, and competitive status. Any given program could hurt some firms while helping others, so virtually every activity must be selective. But some feel industry requests rarely evidence this concern.

\section{Industry's Role}

That the nature of industry and its management is part of the problem is hardly debatable, but most of the charges are too harsh. Certainly dollar budgets for 1978 , 


\section{"The average time to complete the innovative process is 19.2 years . . . one-half of a man's career. But management's time horizon is only about 3 years."}

1979, and 1980 indicate a strong iricreased commitment to R\&D, and industry develops modified products and seemingly minor line extensions in response to market desires, just as we would want them to do.

The question of capital shortage must be taken in the context of the huge cash holdings of firms such as IBM (over $\$ 4$ billion) and evidence that truly profitable opportunities apparently can find capital. And certainly the conservatism of some managements must be compared with the daring of others such as RCA, IBM, Polaroid, Xerox, Texas Instruments, the pharmaceutical companies, Intel, and many more (Sommers, Levy). Even the bureaucratic charge is rather hollow, as viewed by those managements which use decentralization, venture groups, and so on, to overcome it successfully. Besides, Dean feels that what the large firm does is rather irrelevant because the truly significant innovations have come from small firms (p. 27). The Small Business draft report documents this extensively.

\section{Society's Role}

Most of the arguments given earlier which seek to indict society as a cause of the technological decline are opinions or personal desires. There is very little hard data on these issues, and in any event no one would seriously suggest that society does not want new energy sources, anti-arthritics, new modes of "blind sight," lower cost steel, warmer houses, or better lighting.
$\mathrm{W}$ ith some exceptions regarding how it is phrased, there seems to be agreement that:

1. Recent years have seen less real commitment to technological innovation than the years from 1945-1970.

2. The consequence has been an eroding of U.S. economic power relative to that of other countries, especially Japan and Germany.

3. An ultimate consequence of this power loss will be a decline in American material well-being, if the effect is not already showing up in reduced productivity and inflation.

4. Action is called for. But what action depends on which cause the proposer is most concerned about, and there is widespread disagreement on this score.

5. All of the attention this problem has received over the past five years may be paying off. $R \& D$ spending is once again on the rise, exciting technological outputs abound, industry has seriously addressed its management problem, governmental redirection is at least underway, and evidence suggests that society has learned to be selective in its actions and reactions.

However, the entire process of determining the proper role for technological innovation is still one of politics and priorities. The debates summarized here will continue for a long time to come.

1. "The Silent Crisis in $\mathrm{R}$ and D," Business Week, March 8, 1976: 90

2. Robert C. Dean, Jr., "Technical Innovation in U.S.A.," Mechanical Engineering, November 1978: 23-32.

3. Frank H. Healey, "Industry Needs for
Basic Research," Research Management, November 1978: 12-16.

4. Michell C. Lynch, "Backing off Basics," Wall Street Journal, October 18, 1977: 1 .

5. "The Breakdown of U.S. Innovation," Business Week, February 16, 1976: 56-68.

6. George E. Manners, Jr. and Howard K. Nason, "The Decline in Industrial ResearchCauses and Cures," Research Management, September 1978: 8-11.

7. Edward E. David, "U.S. Innovation and World Leadership: Facts and Fallacies," Research Management, November 1977: 7-10.

8. H. R. Clauser, "Perspectives: Forecasts and Budgets Predict Two Growth Years for R\&D," Research Management, March 1979: 2.

9. John Hanley, "The Day Innovation Died," an Address to the Houston Club, Houston, Texas, September 26, 1978.

10 "Eli Lilly," Business Week, October 29, 1979: 134

11. Environment, Health and Safety Regulation: Draft Report, Advisory Committee on Industrial Innovation, Department of Commerce, Washington, D.C., December 20, 1978.

12. Economic and Trade Policy: Draft Re port, Advisory Committee on Industrial Innova tion, Department of Commerce, Washington, D.C., December 20, 1978.

13. William E. Simon, "American Business: A Beleagured Enterprise," Chemical Week, April 4, 1979: 5 .

14. The Effects of Domestic Policies of the Federal Government upon Innovation by Small Business: Draft Report, Industrial Innovation Advisory Committee, Department of Commerce, Washington, D.C., May 1, 1979.

15. "The Chemical Industry and Federal Policy," Chemical and Engineering News, February $5,1979: 26$.

16. Geoffrey Place, "Needed-More Intuitive Applied Research," Research Management, November 1977: 19-23.

17. Robert $R$. Irwing, "Why America's Technology Is in Trouble and What Can Be Done About It," Iron Age, July 31, 1978: 49.71.

18. "U.S. Promotes Patent File as $\mathrm{R}$ and $\mathrm{D}$ Resource," Industrial Research and Development, April, 1979: 62-64.

19. Patent Policy: Draft Report, Advisory Committee on Industrial Innovation, Depart ment of Commerce, Washington, D.C., Decem* ber 20,1978 .

20. Alok K. Chakrabarti, Stephen Feinman, and William Fuentavilla, "Industrial Product Innovation: An International Comparison," Industrial Marketing Management, 7 (1978): 231-237. 
21. "U.S. Research and Development and It's Flow Abroad," Conference Board Record, August 1975: 12-13.

22. Joseph M. Lightman, "Foreign Patent Protection," Business America, August 27, 1979: $3-5$.

23. Regulation of Industry Structure and Competition: Draft Report, Advisory Committee on Industrial Innovation, Department of Commerce, Washington, D.C., December 20, 1978.

24. Evan F. Binkerd, "The Corporate R\&D Operation in Today's Business Climate," Speech before the Food Update, 78 Conference, San Diego, California, 1978.

25. Richard V. Foster and Frederick W. Gluck, "Impact of Anti-Trust and Regulatory Actions on Progress of Technology," Research Management, July 1975: 7-10.

26. Gordon M. Graft, "Charting a Course for Innovation," Chemical Week, April 4, 1979: 38-43.

27. "Chairman Laments Decline in Innovation in U.S.," Automotive News, February 5, 1979: 28.

28. Robert R. Jones, "Hats Off to G.E. Innovation," Industrial Research and Development, September 1979: 11.

29. Kenneth E. Knight and Helen R. Baca, "The Role of Government in Industrial Innova" tion," Long Range Planning, December 1978: 79-88.

30. Donald D. Holt, "Why Eaton Got Out of the Air Bag Business," Fortune, March 12, 1979: 146-149.

31. Wil Lepkowski, "White House Awaits Huge Innovation Report," Chemical and Engineering News, February 12, 1979: 14-16.

32. Federal Procurement Policy: Draft Report, Advisory Committee on Industrial Innovation, Department of Commerce, Washington, D.C., December 22, 1978: 22-25.

33. "OTA Reports on Federal Influence on Innovation," Chemical and Engineering News, October 9, 1978: 12.

34. John J. Mattill, "Innovation-Rising, Falling or Changing?" Technology Review, July-August 1976: 12-14.

35. Bela Gold, "Factors Stimulating Technological Progress in Japanese Industries: The Case of Computerization in Steel," Quarterly Review of Economic and Business, Winter 1978: 7-21.

36. Robert Wesson, "Why Soviet Technology is Lagging," Business Week, February 26, 1979: 11 .

37. James Quinn, "New Approaches for New Public Needs," Research Management, November 1977: 11-18.
38. H. R. Clauser, "Perspectives: New Technological Foundation Planned," Research Management, September 1978: 2-5. H. R. Clauser, "The Role of Industrial R\&D in New Government Programs," Research Management, September 1978: 12-13.

39. William P. Sommers, "Today's Technology Requires Managers with Quick Reflexes," Nation's Business, February 1979: 88-90.

40. C. J. Mosbacher, "Organizing for High Technology," Industrial Research Development, January 1979: 93-98. C. J. Mosbacher, “\$51.8 Billion for R\&D," Industrial Research/ Development, January 1979: 77-79.

41. "The Profit Illusion," Business Week, March 19, 1979: $108 \mathrm{ff}$

42. "Where Genetic Engineering Will Change Insdustry," Business Week, October 22 , 1978: 11 .

43. "U.S. Innovation: Its's Better Than You Think," Dun's Review, March 1978: 55-58.

44. "The Silent Crisis in $R$ and $D ": 91$.

45. "Are you Listening, Jimmy Carter, Teddy Kennedy?" Forbes, January 22, 1979: 56.

46. Richard K. Pitler, "The World Rests Firmly on Steel Technology,"' Steel, 2 (1977).

47. Tuvia Blumenthal, "A Note on the Relationship Between Domestic Reward and Development and Imports of Technology," Economic Development and Cultural Change, January 1979: 303-306.

48. H. R. Clauser, "Perspectives: Manpower News," Research Management, July 1975: 5-6. 49. Anne C. Roark, "U.S. Reverses Decade-Long Decline in Support for Science," NSF Reports," The Chronicle, December 3, 1979: $1 \mathrm{ff}$.

50. Glenn Gilman, "Technological Innovation and Public Policy," California Management Review, Spring 1971: 13-23.

51. R. Jeffrey Smith, "Battelle Forecasts Healthy Growth for R and D in 1979,'"Science, January 19, 1979: 246.

52. Frank Press, "Towards New National Policies to Increase Industrial Innovation," $R e$ search Management, July 1978: 10-13.

53. "ESB Ray-O-Vac: Decentralizing to Recharge its Innovative Spirit," Business Week, March 12, 1979: 116-117.

54. Arthur Gerstenfeld and Keyi Sumiyoshi, "Innovation in Japan Compared to the U.S." Paper delivered to Second Annual Conference, Product Development and Management Association, Boston, Mass., October 5, 1978.

55. "The Silent Crisis in $\mathrm{R}$ and $\mathrm{D} ": 91$.

56. A Statement of the Labor Advisory Subcommittee on Industrial Innovation: Draft
Report, Department of Commerce, Washington, D.C., December 22, 1978

57. "Vanishing Innovation," Business Week, July 3, 1978: $46 \mathrm{ff}$.

58. Edward E. David, "U.S. Innovation and World Leadership: Facts and Fallacies," Re search Management, November 1977: 7-10.

59. Richard J. Levine, "Carter Faces Problems in Achieving the Goals of Fiscal 1980 Budget," Wall Street Journal, January 1, 1979: 7.

60. Robert Levy, "Tomorrow's Growth Industries," Dun's Review, February 1979: 44-48. 